胃亜全摘後の胆のら収縮能

一超音波映像下での検討一

\author{
兵庫医科大学第 2 外科 \\ 高橋 徳 石川 羊男 山村 武平 神頭 勝 \\ 黒木 輝幸太田昌資 楠原 清史 宇都宮譲二
}

\title{
ULTRASOUND MEASUREMENT OF CONTRACTILE MOTILITY OF THE GALLBLADDER AFTER SUBTOTAL GASTRECTOMY
}

\author{
Toku TAKAHASHI, Yoshio ISHIKAWA, Takehira YAMAMURA, \\ Masaru KANTOH, Teruyuki KUROKI, Masashi OHTA, \\ Kiyoshi KUSUHARA and Joji UTSUNOMIYA
}

Second Dept. of Surgery, Hyogo College of Meicine

\begin{abstract}
胃切除後に高頻度に発生する胆のう疾患の原因を収縮運動の面から考察する目的で，過去 1 力月以 内に，胃癌で胃亜全摘訹を施行された患者18名を対象に，ダイヤン経口負荷後の胆のら収樎運動を， 経時的に超音波診断装置にて観察した。胃覀全摘後には，胆のう収縮能の低下がみられたが，特に Billroth II 法による再建術を受けた群では, Billroth I 法に比べ，空腹時胆のう面積は㧪張し，ダイヤ ンによる収縮能も函めて不良であった。胃癌手術時には, 胃切除に加え, リンパ節郭清に伴い, 迷走 神経や交感神経の切離も施行され，これら種々の要因が術後の胆のう機能低下に関与していると考兄 られるが，特に再建術式による食物の十二指腸通過の有無が重要と考えられた。
\end{abstract}

索引用語：胃切後胆石症，胆のう収縮運動

I.はじめに

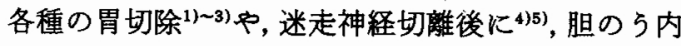
結石や胆のう炎などの胆のう疾患が高頻度で発生する ことが知られている. その機序については不明である が, 手術後の胆汁酸組成の変化と, 胆のう運動機能の 低下の 2 因子が主として考光られており，手術後に増 加した lithogenic bile の胆のう内でのうっ滞が結石形 成過程を助長する可能性が示唆されている6)。これら 手術後に発生する胆のう疾患はその診断の困難さなど から，しばしば重篤な経過をたどることが報告されて

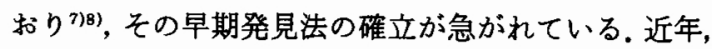
リアルタイム超音波断層装置 (Ultrasonography, 以下 US と略す)の解像力が長足の進歩を遂げ, 胆のう内腔 の微細な病変の描出に威力を発揮するよらになっ た 。 また，その胆のう描出の容易さ，簡便さから，臨

$<1984$ 年 8 月 13 日受理 $>$ 別刷請求先：高橋 徳 T663 西宮市武庫川町 $1-1$ 兵庫医科大学第 2 外 科
休の場での胆のう収縮運動の観察にも導入され，各種

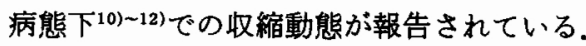

今回, 著者らは胃癌手術後 1 力月以内に US 下で, ダ イヤン経口負荷による胆のら収縮運動を観察した。そ して，この時期では，術式により胆の.5収縮運動の低 下に差異のみられることが示唆された。この収縮力低 下の原因については, 手術による, 機能的, 解剖学的 な環境の変化に伴う, 神経性因子, 体液性因子の複雑 な相互作用機構の破綻が主因と考点られ，胆のう収縮 運動に拈よ济すこれらの種々の因子の生理的, 病理的 な作用をも含めて，この現象の etiologyを考察した い.

\section{II. 対象および方法}

対象は, 胆道系に異常を認めない健常者10名（平均 年秢 49 歳), 過去 1 力月以内に, 胃癌で $\mathrm{R}_{3}$ の手術を施 行された経過良好な患者18名 (平均年齢66歳)である. その内訳は Billroth I 法 (以下 BI) による胃亜全摘群 10名 (平均年龄68歳)，Billroth II 法による胃覀全摘群 
8 名（平均年齡65歳）である，検查は，胃癌手術後， $3 ー 4$ 週経過した時点で，一夜絶食後に行った。リニ ア式電子走查超音波診断装置（Aloka SSD-256）を用 い，胆のう長径が最大となるような右季助下走查法で 胆のうを描出し，USに連動するコンピューターによ り, 胆のう面積を算出した。胆のら収縮剂として乾燥 畉黄製剂（ダイナン顆粒；丸石製薬） $13 \mathrm{~g}$ を水 $40 \mathrm{ml}$ に て溶解後，経口投与し，10分毎に60分後まで胆のら面 積を計測した。

また，健康成人20名（平均年柃26歳）を対象に，ダ イヤン $13 \mathrm{~g}$ の経口負荷時と, セルレイン $0.1 \mu \mathrm{g} / \mathrm{kg}$ の筋 注時の胆のう收縮率の比較孔試みた。胆のう収縮率は 次式により求めた。

胆のう収縮率（\%)

$$
=\left(1-\frac{\text { 胆のう収縮阂負荷後の胆のう面積 }}{\text { 空腹時の胆のう面積 }}\right) \times 100
$$

III. 結 果

1. 健康成人におけるダイヤン経口負荷と, セルレイ
ン筋注による胆のう収樎率の比較

健康成人にダイヤン $13 \mathrm{~g}$ を経口負荷すると，徐々に 胆の5収縮反応が観察され(図 1)，負荷後40分で頂值 $44.4 \pm 2.4 \%$ (mean $\pm \mathrm{SE}$ ) となり, 以後, 次第に回復 した。一方，セルレイン $0.1 \mu \mathrm{g} / \mathrm{kg}$ の筋注では，投与後 20分に最大収縮率38.4士2.8\%が認められた（図 2 ）.

2. 胃亜全摘術前後でのダイヤン投与による収縮運 動の比較

図 3 は胃垔全摘術 (BII) を受けた症例 (63歳, 男性) の手術前後の胆のう収縮能の比較である. 手術前はダ イヤンに良く反応して収縮しているが，手術後に同様 の検査を行ってみると，胆のうの払張が著明であり， 内腔に biliary sludge の貯留を認め, 収縮は極めて不 良であった。

3. 胃覀全摘患者における,ダイヤン投与前後の胆の 5 収縮運動

空腹時の胆のう面積は，BI 群で13.3土1.6 $\mathrm{cm}^{2}$ であ $\eta$, 健常群 $\left(13.0 \pm 1.0 \mathrm{~cm}^{2}\right)$ との間に有意の差を認め

図 1 ダイヤン $13 \mathrm{~g}$ 投与前後の胆のう超音波像.

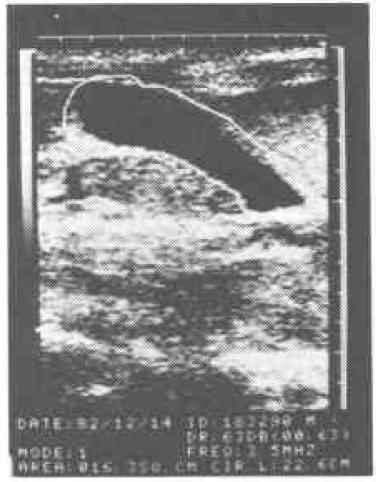

before

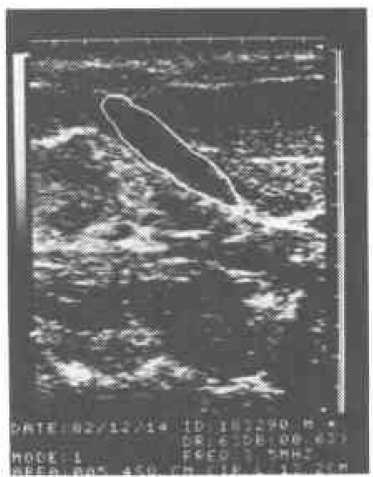

$30 \mathrm{~min}$

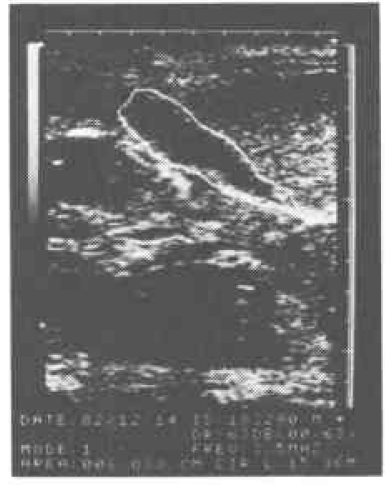

$10 \mathrm{~min}$

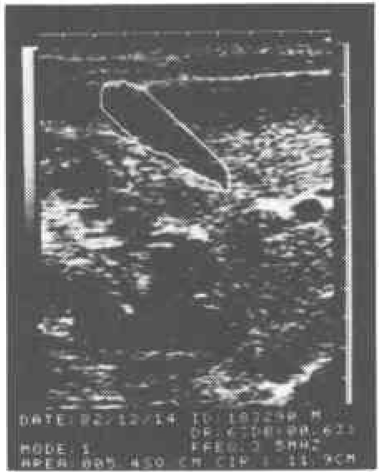

$40 \mathrm{~min}$

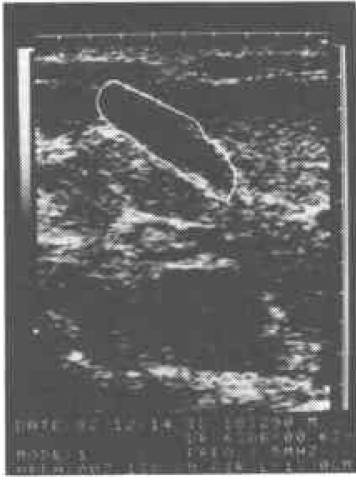

$20 \mathrm{~min}$

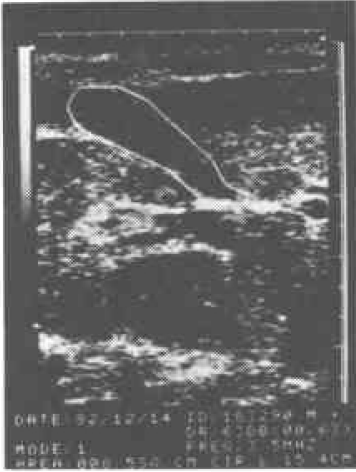

$60 \mathrm{~min}$ 
図 2 健康成人 20 人に拈ける, ダイヤン $13 \mathrm{~g}$ 経口投与 とセルレイン $(0.1 \mu \mathrm{g} / \mathrm{kg})$ 筋注時の胆のう収縮率の 比較.

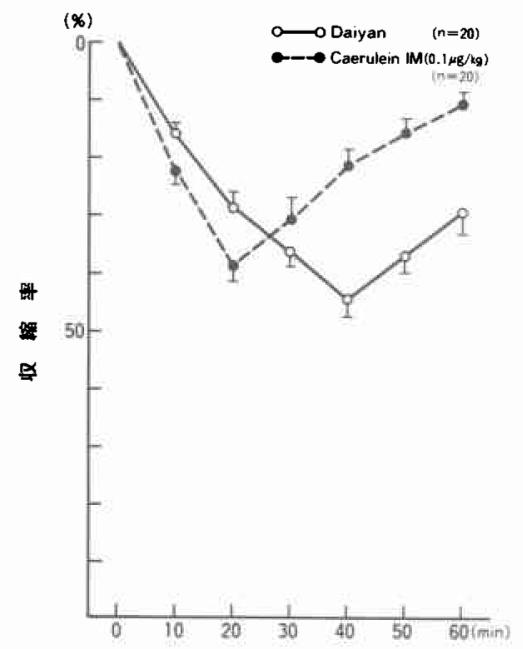

図 3 胃亚全摘術 (BII) 前後の胆のち超音波像と胆の 5收樎能の変化。

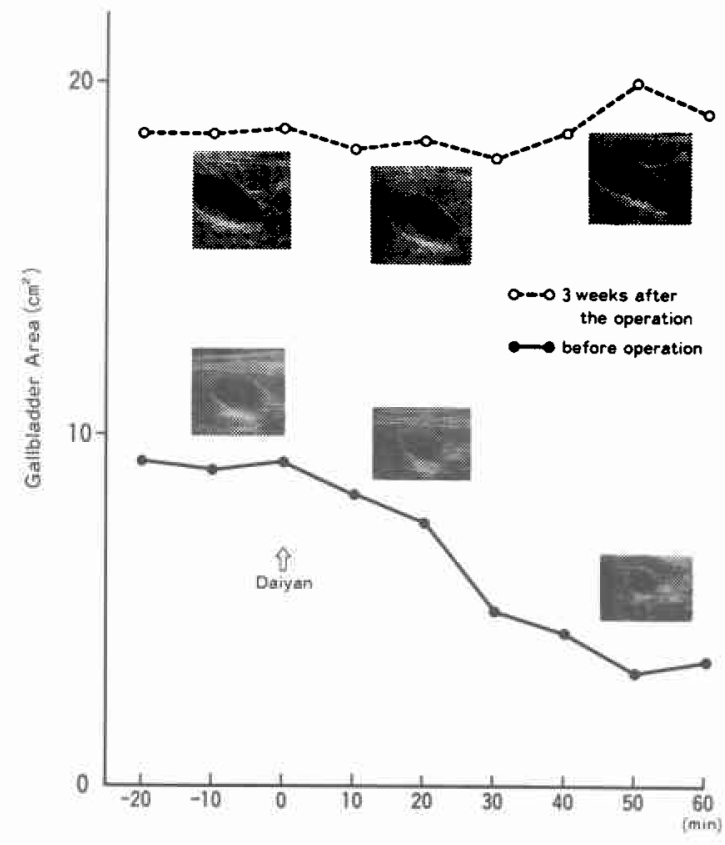

なかったが, BII 群では, $20.6 \pm 1.3 \mathrm{~cm}^{2}$ と有意に $(\mathrm{p}<$ 0.01 ) 払張していた（図4).

ダイヤン服用後, 健常群では, 徐々に胆のう面積の 縮小化が観察され，40分後に最大収縮率 $43.7 \pm 4.7 \%$ を 示したが, 胃切除後にはこの収縮率の低下が顕著と なった(図 5 ). BI 群では，30分後に最大収縮率21.7士
図 4 ダイヤン投与前後の胆のら面積の変化（HC； Healthy Controls, BI ; Billroth I, BII ; Billroth II).

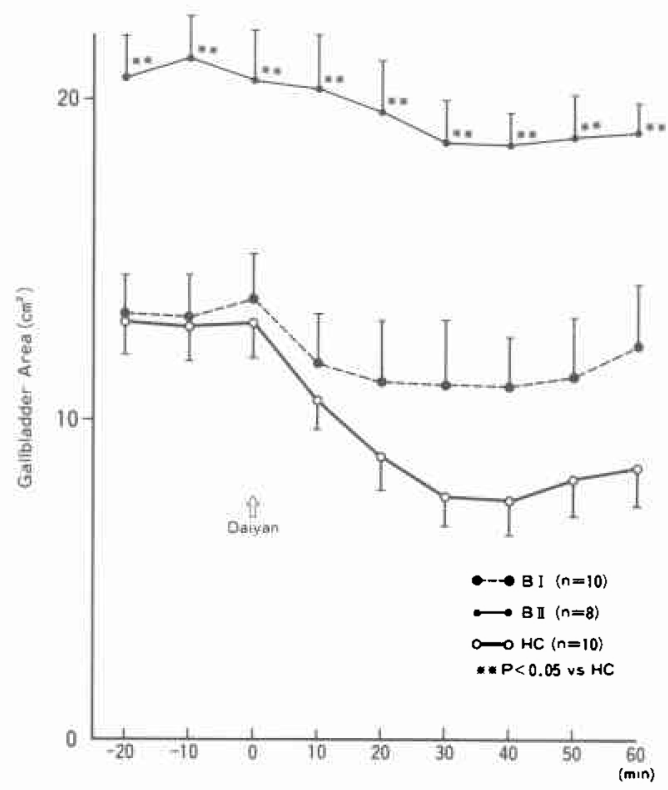

図 5 ダイヤン投与後の胆の5収樎率の変化 (HC; Healthy Controls, BI ; Billroth I, BII; Billroth II).

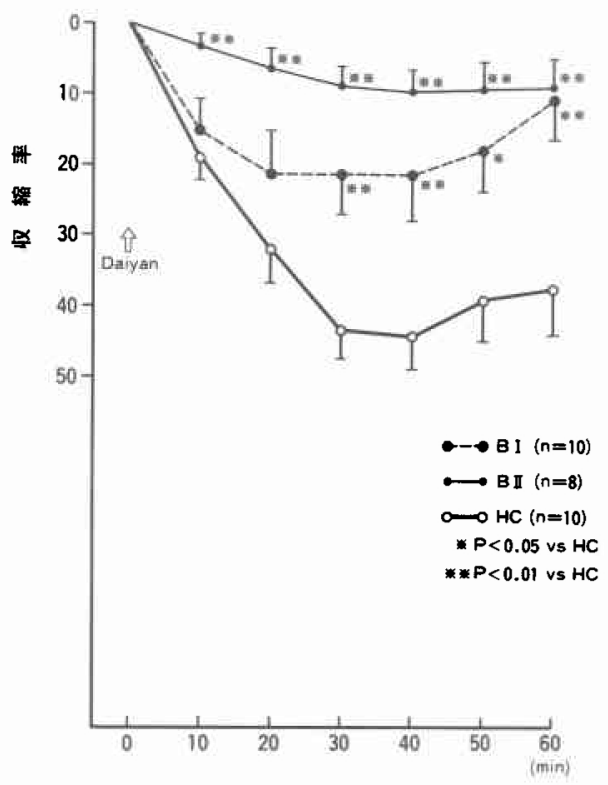

$5.5 \%$ 示し, この値は健常群に比し, 有意に（p< 0.01）低下していた。 また BII 群では胆のら収縮は極 めて不良で40分後に最大収縮率9.6土3.0\%を示したに 過ぎなかった（図6）。 
図6 ダイヤン投与後の最大収縮率 (HC; Healthy Controls, BI ; Billroth I, BII ; Billroth II).

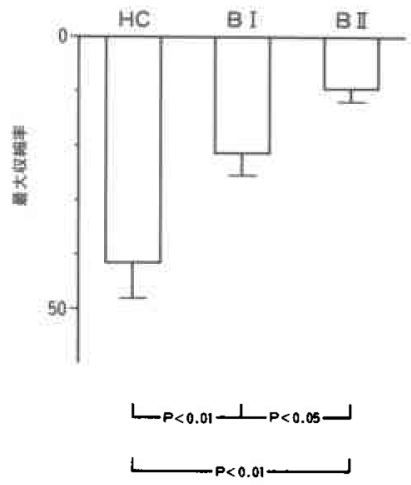

\section{IV. 考察}

胃亜全摘後 1 力月以内にみられた, 胆のら收縮不全 の原因については種々の要因が考兄られる。胆のら収 縮に関与している体液性因子としては cholecystokinin (以下 $\mathrm{CCK})^{1013)}$, motilin ${ }^{13)}$, prostaglandin ${ }^{14)}$, bombesin $^{15)}$, histamine ${ }^{14)}$ などが挙げられるが，その主 役は CCK と考兄られている(10).最近, ガストリン放出 作用を有するbombesin が胆のう平滑筋に対して収縮 作用を持つことが報告され，注目されているが15)，ヒト 胆のう条片を用いた in vitroの著者らの実験では， bombesin はCCK の約 $20 \%$ の収縮力しか認められず (未発表データ), 胆のう収縮運動の担い手としては CCK を第 1 亿考えるべきであろう，従来より，脂肪食 や卵黄の摂取により，著明な胆のうの収縮運動が出現 することが知られているが，この現象は，十二指腸や 上位空腸粘膜から放出される CCK を介した作用であ ると考兄らている。最近, Wiener ら ${ }^{16)}$ はCCKの radioimmunoassay 法を確立し, 健康成人に括いて Triglycerideの服用後にみられる胆のら収縮反応と 相関した血中 CCK 動態を報告している。乾燥卵黄粉 末であるダイヤンは，従来より，胆のう造影時の収縮 剤として広く使用されているが，US下においてその 経口投与により，胆のう面積の縮小化が観察された。 また，図1に示したごとく，その最大収縮率は，七ル レイン $(0.1 \mu \mathrm{g} / \mathrm{kg})$ の筋注時と大差がなく, US 下で のダイヤン経口負荷試験は，正常人において，内因性 CCK 放出動態を推察し得る有効な 1 手段と考えられ た.

胃癌手術に際しては，全摘時はいらにおよばず，亜 全摘時でも，リンパ節郭清により，迷走神経が犠牲に
され，この迷走神経切離の胆のう運動におよぼす影響 についての検討は, 特に重要である。迷走神释（走行 する遠心性線維の大部分がコリン作動性神経と考えら れるが)の胆のう運動に対する作用点として，1）空腹 時の胆の 5 tonus の維持作用,2）脂肪食や卵黄の刺激 により十二指腸，上位空腸粘膜から放出される CCK の分泌機構に対する作用，3）放出された CCK の胆の ら収縮効果に対する相互作用，の 3 点が特に重要な問 題と考えられる.

胆のう tonus の維持に対する迷走神経の作用につい ては，全幹迷切(TV) 前後で差が無いとする報告 ${ }^{17) ~ 19) ~}$ と TV 後に tonus の低下が生じるという報告(20)21)が あり，末だ統一をみていない，Glanville ら ${ }^{17)}$ は，TV 後 2 週間 3 力月の患者に胆の5造影を行い, $\mathrm{TV}$ 前 後で空腹時胆のう面積に差がみられなかったと報告 し, イヌを用いた実験 ${ }^{18) 19)}$ でも同様に, TV 後 $3 \sim 10$ 週 間では胆のう面積や内圧に差が無いことが示されてい る. 一方, Parkin 5 ${ }^{201}$ は, 各種迷切術後, $2 \sim 3$ 年の 患者を対象に, 空腹時胆のら容量を観察し，TV 後で は, 胆のう容量の拡張が著しいが, Selective Vagotomy (SV) 後ではコントロール群と差が無いこ とより, 胆のう tonus の機能維持に迷走神経肝枝の重 要性を強調している. 同様の結果は, 迷切後 $4 \sim 7$ 年4), 3 12力月21)の患者においてす提出されている. このような TV 後の胆のう tonusに対する実験結果 の差異については不明であるが Ryan ${ }^{22)}$ は，迷切の影 隌は数カ月以上経て徐々にあらわれてくるためであろ らと推察している。 また，胆のう壁内神経叢中のコリ ン作動性神経 ${ }^{23)}, \mathrm{CCK}$ 神経 ${ }^{24)}$, ATP 神経 ${ }^{25) 26)}$, VIP 神

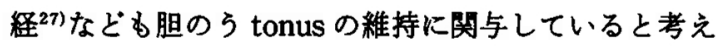
られており，迷切により中权神経支配から隔離された 状態では，その機能に変化が生じる可能性るあり，注 目すべきであろう。

胃亜全摘術では, BI 法, BII 法を問わずリンパ節郭 清の際に，迷走神経肝枝は切離されているが，今回の 著者らの結果では, 空腹時の胆の5面樌の拡張は, BII 群にのみ認められており，その原因を迷切には求め難 い.

迷切の CCK 遊離におよぼす影響については，血中 CCKの測定上の困難さなどから，その報告は極めて少 ないが, 最近, Fried ら ${ }^{19}$ はイヌの TV 前後で, オレイ ン酸塩投与による胆のう収縮圧と, 血中 CCK レベル を測定し，迷切後にはオレイン酸による胆のう収縮圧 の低下がみられるが，血中 CCK 遊離には迷切前後で 
変化が無かったと報告しており，興味深い。

$\mathrm{TV}$ 後には, 外因性の CCK に対して胆のう CCK 受 容体の感受性が増すといら報告28299に対して，その反 応性に変化が無いといら報告1823/30) すり，この点に 関しても一定の見解が得られていない. 最近,さらに Takahashi ら ${ }^{131}$ は, CCK の収縮が atropine に上る薬 物迷切で减弱されたと報告し, 両者の競合的な拮抗作 用の可能性を提示している，代表的な神経ペプチドの 1 員でもある CCK は, その受容体がラットの迷走神 経内にも発見され ${ }^{31}$, $\mathrm{CCK}$ と迷走神経の相互作用の解 明に新たな観点が示されている。著者らも，CCK 受容 体が胆のう平滑筋細胞のみでなく, 壁内神経鋠中のコ リン作動性神経にも存在する可能性 ${ }^{32) 33)}$ を考えてお。 ク, 迷切後には, これらの受容体に機能的, 解剖学的 な変化が生じる可能性も十分に考兄られ，今後詳細に 検討すべきであろう。

同程度の胃切除と神経切除が施行されたにもかかわ らず, BI 群と BII 群との間にみられた, 空腹時胆のう 面積とダイヤンによる収縮能の著明な美異について は, 現在のところ, 著者らは, 再建術式の差, すなわ ち，食物が十二指腸を通過するか否かが重要であろう と推察している.著者らは, 以前に Pancreatic Polypeptide (PP) 遊離に際して, entero-PP axisにおける 十二指腸の価值を見出しているが34), CCK 放出機構に 関してもその可能性が大と考えられる. Pancreatic Function Diagnostant (PFD) に上る朠外分泌機能に ついても, 手術後, 8〜14日では, BII 群で BI 群に比 べ，有意の低下がみられており ${ }^{35}$ 興味深い。

胃切除にみられる胆石症発生頻度は, $13 \sim 42 \%{ }^{213)}$ と されているが, Lundman ら゙ BI 後に Griffiths ら²) はBII 後に多かったと報告している. 特に Griffiths ら²) BII 後に多い理由として, 消化経路からの十二 指腸の隔離の重要性を示唆しており注目される。

しかし，BI 群，BII 群を問わず，ともに胃切除後 1 カ月以内では, 健常群に比し, 収縮率が低值であり, またダイヤンによる収縮反応が不良な症例では，七ル レイン筋注に対する反応す同様に不良であるので（未 発表データ）術後に認められた収縮能低下の原因を全 て CCK 放出の減少にのみ㷌因させることは困難と考 えられる。

最近, 絶食下での高カロリー輸液施行時での急性胆 の5炎の発生頻度が注目されている ${ }^{36)}$.そして,このよ

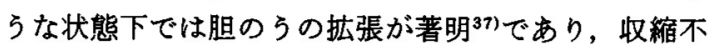
全が示唆されている，今回の著者らの結果に, 胃手術
後 3〜4 日間程度の絶食状態が関与している可能性は 少ないと考えられるが，胆のう収縮運動について考察 するらえで示唆に富む現象である。

\section{V. 結 論}

過去 1 カ月以内に胃癌で胃垔全摘術を施行された患 者18名を対象にダイヤン服用後の, 胆のら收縮運動を USにて観察し，以下の結論を得た。

1. BII 群では, BI 群に比べ, 空腹時胆のう面積の払 張が著明であった。

2. 胃严全摘後 1 力月では,ダイヤン経口負荷による 胆のら収縮能に低下がみられたが, 特に BII 群で著明 であった。

3. 胃癌手術後の胆のう收縮能低下の一因に, 再建術 式による食物の十二指腸通過の有無が示唆された。

\section{文 献}

1) Fletcher DM, Clark CG: Gall-stones and gastric surgery. Br J Surg 55:895-899, 1968

2) Giffiths JMT, Holmes G: Cholecystitis following gastric surgery. Lancet $10: 780-781,1964$

3) Lundman $T$, Orinus $E$, Thorsen $G$ : Incidence of gallstone disease following partial gastric resection. Acta Chir Scand 127 : 130-133, 1964

4) Ihasz $M$, Griffith $C$ : Gallstones after vagotomy. Am J Surg $141: 48-50,1981$

5) Sapala MA, Sapala JA, Resto SO et al: Cholelithiasis following subtotal gastric resection with truncal vagotomy. Surg Gynecol Obstet $148: 36-38,1979$

6) Shaffer FA: The effect of vagotomy on gallbladder function and bile composition in man. Ann Surg $195:$ :413-418, 1982

7) Ottinger LW : Acute cholecystitis as a postoperative complication. Ann Surg 184: $162-165,1976$

8) Jönsson PE, Anderson A: Postoperative acute acalculous cholecystitis. Arch Surg 111: 1097-1100, 1976

9）伊藤信義, 高橋 徳：胆烡癌の診断. 消外 5 ： $165-172,1982$

10) Thompson JC, Fried GM, Ogden WD et al: Correlation between release of cholecystokinin and contraction of the gallbladder in patients with gallstones. Ann Surg $195: 670-676,1982$

11) Everson GT, Mckinley $C$, Lawson $M$ et al : Gallbladder function in the human female: Effect of the ovulatory cycle, pregnancy and contraceptive steroids. Gastroenterology 82 : $711-719,1982$

12) Okulski TA, Eikman EA, Williams JW: 
Ultrasound measurement of contraction response of the gallbladder: Comparison with the radionuclide test for cystic duct patency. Clin Nucl Med 7 : 117-121, 1982

13) Takahashi I, Suzuki $T$, Aizawa $I$ et al: Comparizon of gallbladder contractions induced by motilin and cholecystokinin in dogs. Gastroenterology $82: 419-424,1982$

14）高橋 徳, 山村武平, 石川羊男：モルモット胆の3 条片の収縮運動におよ代す progesterone の影璘。 日消病会誌 $80 ： 1754-1759,1983$

15) Corraziani E, Harib F, Fave GFD et al: Gastrointestinal and gallbladder motor effects of bombesin in man. Mater Med Pol 2 : 139-143, 1977

16) Wiener i, Inoue $\mathrm{K}$, Fagan $\mathrm{CJ}$ et al : Release of cholecystokinin in man, correlation of blood levels with gallbladder contraction. Ann Surg $194: 321-327,1981$

17) Glanville JN, Duthie HL: Contraction of the gallbladder before and after total abdominal vagotomy. Clin Radiol 15 : 350-354, 1964

18) Andrup BM, Griffith $\mathrm{CH}$ : The effects of vagotomy upon billiary function in dogs. J Surg Res $10: 209-212,1970$

19) Fried GM, Ogden WD, Greeley G et al: Correlation of release and actions of cholecystokinin in dogs before and after vagotomy. Surgery $93: 786-791,1983$

20) Parkin GJS, Smith RB, Johnston D: Gallbladder volume and contractility after truncal, selective and highly selective (partial cell) vagotomy in man. Ann Surg $178: 581-586$, 1973

21) Rudick J, Hutchinson JSF : Effects of vagalnerve section on the billiary system. Lancet $14: 579-581,1964$

22) Ryan JP: Motility of the gallbladder and billiary tree. In: Phisiology of the Gastrointestinal Tract. Edited by LR Johnson. New York, Raven Press, 1981, p473-494

23) Liedberg $G$ : The effect of vagotomy on gallbladder and duodenal pressures during rest and stimulation with cholecystokinin. Acta Chir Scand $135: 695-700,1969$

24) Davison JS, Farashah AN : Dibutyryl cyclic GMP, a competitive inhibition of cholecystokinin/pancreozymin and related peptides in the gallbladder and ileum. Can J Physiol Pharmacol 59: 1100-1104, 1981

25）石川羊男, 高橋 徳, 山村武平：モルモット胆のう 条片の運動に対する adenosine 5 '-triphosphate の作用と各種ブリン受容体遮断剂の影響. 日平滑 筋会誌 $19: 1-7,1983$

26) Ishikawa $Y$, Takahashi $T$, Yamamura $T$ : Effects of apamin and theophylline on adenosine $5^{\prime}$-triphosphate induced responses of the guinea pig gallbladder. Digestion 27 : 234-238, 1983

27) Sundler F, Almets J, Hakanson R et al : VIP innervation of the gallbladder. Gastroenterology $72: 1375-1377,1977$

28) Tinker J, Cox AG: Gall-bladder function after vagotomy. Br J Surg 56:779-782, 1969

29) Malagelada JR, Go VLW, Summerskill WHJ : Altered pancreatic and biliary function after vagotomy and pyloroplasty. Gastroenterology $66: 22-27,1974$

30) Isaza J, Jones DT, Dragstedt LR et al: The effect of vagotomy on motor function of the gallbladder. Surgery $70: 616-621,1971$

31) Zarbin MA, Warmsly JK, Innis RB et al: Cholecystokinin receptors: Presence and axonal flow in the rat vagus nerve. Life Sci 29 : 697-705, 1981

32）高橋徳, 山村武平, 石川羊男ほか：モルモット胆 のう条片におよぽす cholecystokinin octapeptideの影篦. 消化管ホルモン（IV）, 消化管ホル モ研究会編, 医学図畫出版, 東京, 1984, p133-140

33）高橋 徳, 神頭 勝, 山村武平活か：モルモッ卜胆 の 5 からの acetylcholine 放出に対する cholecystokinin octapeptide の影留. 医のあゆみ $128: 731-732,1984$

34) Yamamura $T$, Seino $Y$, Mori $K$ et al: Possible role of the duodenum in the entero-PP axis. Regul Pept 6:189-196, 1983

35）三輪正彦：消化管術後とPFDテスト，胆と椫 2 : 1495-1500, 1981

36) Roslyn JJ, Pitt HA, Mann LL et al: Galbladder disease in patients on long term parenteral nutrition: Gastroenterology $84: 148-154,1983$

37) Barth RA, Brasch RC, Filly RA: Abdominal pseudotumor in childhood: Distended gallbladder with parenteral hyperalimentation. Am J Radiol 136:341-343, 1981 